\title{
PENGARUH PENDAPATAN SENDIRI, JENIS PEMERINTAH DAERAH DAN LETAK PEMERINTAH DAERAH TERHADAP PERILAKU OPORTUNISTIK LEGISLATIF DI DEWAN PERWAKILAN RAKYAT KABUPATEN ACEH UTARA
}

\author{
Murhaban $^{1}$, Aris Munandar ${ }^{2}$ \\ ${ }^{1,2}$ Prodi Akuntansi Fakultas Ekonomi dan Bisnis Universitas Malikussaleh Lhokseumawe \\ $\underline{\text { murhaban@unimal.ac.id }}$, $\underline{\text { arismunndar74@gmail.com }}{ }^{2}$
}

\begin{abstract}
The purpose of this study was to learn to find out their own income, types of regional government and regional government related to opportunistic legislatures in the North Aceh District People's Representative Council (DPRK). The sample in this study amounted to 45 respondents taken from 45 members of the North Aceh District Representative Council. Data obtained by collecting questionnaires. The data analysis technique used is a simple linear regression analysis technique. The results of the study indicate their own expenditure on legislative opportunistic policies in North Aceh District. From the results of the research conducted with the facts issued regarding the contribution to the opportunistic legislature because of this, the income itself is related to the importance of development in development in North Aceh District. The type of regional government towards legislative opportunistic behavior has a positive and significant influence. The results of the study indicate that there are differences between the types of regional government which will facilitate the government in carrying out the duties of the board members who regulate the budget allocation process in each development as expected. Regional laws related to legislative opportunistic behavior have a positive and significant relationship. The results of the study indicate that there is a regularity of regional government that will make it easier for the government to supervise legislative opportunists that are as expected. The calculated $F$ value is 12,534 with a significance level of 0,000 . While Ftable with a confidence level of $95 \%(\alpha=5 \%)$ on the probability of 0.05 and $d f 2=n-k-1(45-4=41)$ and obtained the value of Ftable of 3.998. Then the F-test results show that Fcount> Ftable (12,534>4,078).
\end{abstract}

Keywords: Own Income, Type of Regional Government and LocationRegional government, legislative opportunistic behavior.

\section{PENDAHULUAN}

Kebijakan autonomi daerah di Indonesia telah membawa perubahan yang sangat mendasar terhadap hubungan Pemerintah Daerah (eksekutif) dengan Dewan Perwakilan Rakyat Daerah (DPRD) atau legislatif. Hal ini menunjukkan bahwa di antara legislatif dan eksekutif terjadi hubungan keagenan (Halim, 2002; Halim \& Abdullah, 2006). Perubahan ini juga berimplikasi pada kian besarnya peran legislatif dalam pembuatan kebijakan publik, termasuk penganggaran daerah.

Secara faktual di Indonesia saat ini banyak mantan dan anggota legislatif yang divonis bersalah oleh pengadilan karena menyalahgunakan APBD. Kemungkinan hal ini terkait dengan peran legislatif yang sangat besar dalam penganggaran, terutama pada tahap perencanaan atau perumusan kebijakan anggaran dan pengesahan anggaran. Dugaan adanya misalokasi dalam anggaran karena politisi memiliki kepentingan pribadi dalam penganggaran dinyatakan oleh Keefer \& Khemani (2003), Mauro (1998a, 1998b), dan Tanzi \& Davoodi (2002).Kondisi powerful yang dimiliki legislatif menyebabkan tekanan kepada eksekutif menjadi semakin besar. Posisi eksekutif yang "lebih rendah" dari legislatif membuat eksekutif sulit menolak "rekomendasi" legislatif dalam pengalokasian sumberdaya yang memberikan keuntungan kepada legislatif, sehingga menyebabkan outcome anggaran dalam bentuk pelayanan publik mengalami distorsi dan merugikan publik. Dengan demikian, meskipun penganggaran merupakan bagian dari sistem informasi yang dapat digunakan untuk mengurangi oportunisme agen (Eisenhardt, 1989), kenyataannya dalam proses pengalokasian sumberdaya selalu muncul konflik kepentingan di antara actors (Jackson, 1982). Untuk menjelaskan fenomena self-interest dalam penganggaran publik tersebut, teori keagenan dapat dipakai sebagai landasan teoretis (Christensen, Smith dan Bertozzi, 1998).

Alokasi sumberdaya dalam anggaran mengalami distorsi ketika politisi berperilaku korup. Perilaku korup ini terkait dengan peluang untuk mendapatkan keuntungan pribadi pada proyek-proyek yang akan dibiayai dengan anggaran, yakni pengalokasian akan lebih banyak untuk proyek-proyek yang mudah dikorupsi (Mauro, 1998) dan memberikan keuntungan politis bagi politisi (Keefer \& Khemani, 2003). Artinya, korupsi dan rent-seeking activities di pemerintahan berpengaruh terhadap jumlah dan komposisi pengeluaran pemerintah.

Menurut Garamfalvi (1997), korupsi dapat terjadi pada semua level dalam penganggaran, sejak perencanaan sampai pada pembayaran dana-dana publik. Korupsi secara politis (political corruption) terjadi pada fase penyusunan anggaran di saat mana keputusan politik sangat dominan, dengan cara mengalihkan alokasi sumberdaya publik. Sementara korupsi yang terjadi dalam pelaksanaan anggaran 
disebut korupsi administratif (administrative corruption) karena keputusan administrasi lebih dominan. Pada akhirnya korupsi politik akan menyebabkan korupsi administratif.Dalam perkembangannya kemudian, posisi legislatif yang kuat berdasarkan Undang-UndangNomor 22 Tahun1999 mengalami perubahan setelah Undang-Undang tersebut diganti dengan Undang-UndangNomor tahun 2004. Salah satu perubahan terpenting adalah dalam hal pemilihan kepala daerah, yang dipilih langsung oleh rakyat tanpa melalui perantaraan legislatif, sehingga pemberhentian kepala daerah juga bukan kewenangan dari legislatif. Selain itu, Peraturan PemerintahNomor 110 tahun 2000 yang mengatur kedudukan keuangan Dewan Perwakilan Rakyat Daerah (DPRD), yang mengandung kemungkinan bias interpretasi atas anggaran Dewan Perwakilan Rakyat Daerah (DPRD), diganti dengan Peraturan PemerintahNomor 24 Tahun 2004, perubahan ini diharapkan mengurangi perilaku oportunistik legislatif dengan memanfaatkan discretionary power yang dimilikinya (Halim \& Abdullah, 2006).

Kemudianuntuk mengadakan penelitian lebih lanjut yang dituangkan dalam bentuk sebuah skripsi, dengan judul "Pengaruh Pendapatan Sendiri, Jenis Pemerintah Daerah Dan Letak Pemerintah Daerah Terhadap Perilaku Oportunistik Legislatif Di Dewan Perwakilan Rakyat Kabupaten Aceh Utara".

\section{TINJAUAN PUSTAKA \\ Penganggaran Publik dan Politik Anggaran}

Hubungan eksekutif dan legislatif dapat dipandang sebagai hubungan principal-agent (Fozzard, 2001; Halim, 2004b; Moe, 1984; Smith \& Bertozzi, 1998; Yuhertiana, 2003). Dalam hubungan tersebut, pemerintah daerah sebagai eksekutif adalah agent, sementara DPRD sebagai legislatif adalah principal. Menurut Elgie \& Jones (2001), yang berperilaku oportunistik kemungkinan tidak hanya agent, tetapi juga principal. Mardiasmo (2003) berpandangan bahwa DPRD berada dalam posisi dual accountability, akuntabilitas ganda atau dua arah, yang dapat diartikan DPRD sebagai prinsipal bagi eksekutif sekaligus sebagai agent bagi publik atau masyarakat yang memilihnya.

Penganggaran setidaknya mempunyai tiga tahapan, yakni (1) perumusan proposal anggaran, (2) pengesahan proposal anggaran, dan (3) pengimplementasian anggaran yang telah ditetapkan sebagai produk hukum (Samuels, 2000).Sedangkan menurut Von Hagen (2002) penganggaran terbagi ke dalam empat tahapan, yaitu executive planning, legislative approval, executive implementation, dan ex post accountability. Pada kedua tahapan pertama terjadi interaksi antara eksekutif dan legislatif dan politik anggaran paling mendominasi, sementara pada (dua) tahap terakhir hanya melibatkan birokrasi sebagai agent.

\section{Proses Penyusunan Anggaran di Indonesia}

Penerapan autonomi daerah di Indonesia tak terlepas dari perubahan paradigma dalam pengelolaan dan penganggaran daerah. Penganggaran kinerja (performance budgeting) merupakan konsep dalam penganggaran yang menjelaskan keterkaitan antara pengalokasian sumberdaya dengan pencapaian hasil yang dapat diukur. Penganggaran berbasis kinerja mulai diterapkan di Indonesia berdasarkan PP 105/2000 dan Kepmendagri 29/2002 pada tahun anggaran 2003 atau 2004. Anggaran kinerja mendorong partisipasi dari stakeholders sehingga tujuan pencapaian hasil sesuai dengan kebutuhan publik. Legislatif diberi kesempatan untuk berperan aktif dalam penyusunan dan penetapan anggaran sebagai produk hukum.

Proses penyusunan anggaran dalam penganggaran kinerja dimulai dari satuan kerja-satuan kerja yang ada di Pemda, melalui dokumen usulan anggaran yang disebut Rencana Kerja dan Anggaran Satuan Kerja Perangkat Daerah (RK SKPD). RK SKPD kemudian diteliti oleh tim anggaran eksekutif untuk dinilai kelayakannya (berdasarkan urgensi dan ketersediaan dana) diakomodasi dalam RAPBD yang akan disampaikan kepada legislatif. RAPBD kemudian dipelajari oleh panitia anggaran legislatif dan direspon oleh semua komisi dan fraksi dalam pembahasan anggaran.Dalam pembahasan anggaran, eksekutif dan legislatif membuat kesepakatan-kesepakatan yang dicapai melalui bargaining (dengan acuan KUA dan SP) sebelum anggaran ditetapkan sebagai suatu peraturan daerah.Anggaran yang telah ditetapkan menjadi dasar bagi eksekutif untuk melaksanakan aktivitasnya dalam pemberian pelayanan publik dan acuan bagi legislatif untuk melaksanakan fungsi pengawasan dan penilaian kinerja eksekutif dalam hal pertanggungjawaban kepala daerah.

\section{Penganggaran Daerah \\ Hubungan Keagenan dalam Penganggaran Sektor Publik}

Teori keagenan yang menjelaskan hubungan prinsipal dan agen berakar pada teori ekonomi, teori keputusan, sosiologi, dan teori organisasi. Teori keagenan menganalisis susunan kontraktual di antara dua atau lebih individu, kelompok, atau organisasi. Salah satu pihak (principal) membuat suatu kontrak, baik secara implisit maupun eksplisit, dengan pihak lain (agent) dengan harapan bahwa agen akan bertindak/melakukan pekerjaan seperti yang diinginkan oleh prinsipal. Lupia \& McCubbins (2000) menyatakan: delegation occurs when one person or group, a principal, select another person or group, an agent, to act on the principal's behalf. Menurut Ross (1973) contoh-contoh hubungan keagenan sangat universal.

Teori keagenan berfokus pada persoalan asimetri informasi: agents mempunyai informasi lebih banyak tentang kinerja aktual, motivasi, dan tujuannya yang sesungguhnya, yang berpotensi menciptakan moral hazard dan adverse selection. Prinsipal sendiri harus mengeluarkan biaya (costs) untuk memonitor kinerja agents dan menentukan struktur insentif dan monitoring yang efisien (Petrie, 2002). Adanya asimetri informasi di antara eksekutiflegislatif dan legislatif-pemilih menyebabkan terbukanya ruang bagi terjadinya perilaku oportunistik dalam proses penyusunan anggaran, yang justru lebih besar daripada di dunia bisnis yang memiliki automatic checks berupa persaingan (Kasper \& Streit, 1999). 


\section{Hubungan Keagenan Antara Eksekutif dan Legislatif}

Dalam hubungan keagenan antara eksekutif dan legislatif, eksekutif adalah agen dan legislatif adalah prinsipal (Halim \& Abdullah, 2006; Fozzard, 2001; Moe, 1984; Strom, 2000). Lupia \& McCubbins (1994) menyatakan bahwa:the legislator's problem can be characterized as one of a broad class of phenomena known as agency problems... In the legislative policymaking setting, a legislature as a whole acts as principal that delegates to an expert agent (such as the government or a congressional committee) the task of proposing alternatives to an existing policy. The principal-agent interaction in which we are interested begins after the agent makes a proposal and ends when the principal-the full legislature either accepts the proposal or rejects it in favor of the existing policy."

\section{Hubungan Keagenan Antara Legislatif dan Publik (Voters)}

Groehendijk (1997) menyatakan

bahwa without doubt, the relationship between voters and politicians in a representative democracy can be considered to be a principal-agent relationship. Legislatif (politisi) adalah agen dan publik (pemilih) adalah prinsipal (Fozzard, 2001; Moe, 1984). Lupia \& McCubbins (2000) dan Andvig et al. (2001) menyatakan bahwa citizens atau voters adalah prinsipal bagi perlemen. Mitchell (2000) lebih tegas menyatakan bahwa voters adalah the ultimate principals.

Von Hagen (2002) berpendapat bahwa hubungan keagenan antara voters-legislatif pada dasarnya menunjukkan bagaimana voters memilih politisi untuk membuat kebijakan publik bagi mereka dan mereka memberikan dana dengan membayar pajak. Dengan demikian, politisi diharapkan mewakili kepentingan prinsipalnya ketika legislatif terlibat dalam pengalokasian anggaran. Pada kenyataannya, legislatif tidak selalu memiliki preferensi yang sama dengan publik (Groehendijk, 1997). Oleh karena itu, Lupia \& McCubbins (2000) mengingatkan bahwa pendelegasian memiliki konsekuensi terjadinya abdication, yakni agents are unconstrained by how their actions affect their principals. Persoalan abdication menjadi semakin nyata ketika tidak ada institusi formal yang berfungsi mengawasi kinerja legislatif.

\section{Perilaku Oportunistik Legislatif \\ Peran Legislatif dalam Penganggaran}

Selama dua dekade terakhir peran legislatur dalam pembuatan kebijakan publik dan penganggaran semakin meningkat (Schick, 2001). Dengan menggunakan studi kasus pada empat agency, Johnson (1994) menemuka bahwa birokrasi merespon tekanan yang diberikan oleh legislatur dalam proses pembuatan kebijakan dan anggaran. Hyde \& Shafritz (1978:324) menyatakan bahwa penganggaran adalah sebuah proses legislatif. Apapun yang dibuat eksekutif dalam proses anggaran, pada akhirnya tergantung pada legislatif karena legislatif mempunyai kekuasaan untuk mengesahkan atau menolak usulan anggaran yang diajukan eksekutif.

Dobell \& Ulrich (2002) menyatakan bahwa peran penting legislatif adalah mewakili kepentingan masyarakat, pemberdayaan pemerintah, dan mengawasi kinerja pemerintah. Ketiga peran ini menempatkan legislatur berkemampuan memberikan pengaruh signifikan terhadap kebijakan pemerintah. Sementara menurut Havens (1996), tidak ada keharusan bagi legislatif untuk mempunyai preferensi yang sama dengan pemerintah atas kebijakan, termasuk anggaran.

\section{Oportunisme Legislatif dalam Penganggaran}

Teori prinsipal-agen menjelaskan bahwa pihakpihak yang terlibat dalam proses penyusunan anggaran memiliki kecenderungan untuk memaksimalkan utilitasnya melalui pengalokasian sumberdaya dalam anggaran yang ditetapkan (Magner \& Johnson, 1995). Eksekutif atau agency yang menjadi pengusul anggaran dan juga pelaksana atau pengguna dari anggaran tersebut berupaya untuk memaksimalkan jumlah anggaran (Smith \& Bertozzi, 1998). Di sisi lain, publik memilih politisi untuk membuat keputusan tentang penggunaan sumberdaya bagi mereka di pemerintahan sehingga belanja publik sesungguhnya adalah cerita tentang beberapa politisi yang menghabiskan uang orang lain (Von Hagen, 2002).

Politisi dapat memanfaatkan posisinya untuk memperoleh rents. Manipulasi politis atas kebijakan publik menyebabkan pengalokasian sumberdaya dalam anggaran tidak efektif dan efisien.Politisi sebagai agen publik berlaku shirking karena adanya asimetri informasi dan konflik kepentingan dengan konstituennya. Menurut Garamfalvi (1997), politisi menggunakan pengaruh dan kekuasaan untuk menentukan alokasi sumberdaya, yang akan memberikan keuntungan pribadi kepada politisi. Martinez-Vasquez et al. (2004) menyatakan bahwa "Political corruption arises when politicians or senior-level bureaucrats are able to capture the state apparatus for their own private benefit or for the benefit of those close to them. Political corruption does not regularly involve the direct execution of openly illegal or fraudulent activities, but rather the use of political power to influence the resource allocation process or the regulatory framework so that private gains are obtained as a result of public power under the veil of "legal" means."

Teori ekonomi dan common sense menunjukkan bahwa jenis-jenis belanja pemerintah membuka peluang untuk lucrative opportunities (Mauro, 1998a). Isu-isu penting dalam pengalokasian sumberdaya ke dalam belanja publik adalah (1) rent-seeking behavior(Krueger, 1974) dan (2) pemilihan barang atau pelayanan untuk programprogram yang sulit untuk dimonitor orang lain (Mauro, 1998a; 1998b). Misalnya, belanja untuk barang-barang khusus dan berteknologi tinggi merupakan contoh belanja yang mudah dikorupsi karena tidak banyak atau tidak ada orang yang memahami barang tersebut (Shleifer \& Vishny, 1993). 
Representasi politik yang tidak layak dan institusi yang lemah mengakibatkan banyak peluang untuk melakukan political corruption.Menurut Camarer (1997) tindakan korup tidak demokratis. Beberapa faktor institusional dapat memberi peluang bagi terjadinya political corruption ini, yakni:

1. Adanya discretionary systems dalam pembuatan keputusan dan kurangnya mekanisme perencanaan partisipatif;

2. Ketidaklengkapan dalam formulasi anggaran; dan

3. Ketiadaan regulasi mengenai rent-seeking (Martinez-Vasquez et al., 2004).

Kecenderungan misalokasi dalam pengeluaran pemerintah merupakan bagian dari pertarungan politik di antara politisi, yang tidak pernah menguntungkan kaum miskin.Ketika keputusan pengalokasian dibuat, motivasi terhadap preferensi pengeluaran terkait dengan moral hazard legislatif.Preferensi legislatif adalah pada proyek infrastruktur karena lebih mudah digunakan sebagai bentuk pemenuhan atas janji kepada voters-nya (Keefer \& Khemani, 2003).Sektor pendidikan dan kesehatan merupakan kebutuhan dasar rakyat yang semestinya diberikan oleh pemerintah dan sangat berpengaruh terhadap pertumbuhan ekonomi (Davoodi et al., 2003; Gupta et al., 2002), sehingga keberpihakan legislatif kepada sektor ini merupakan keniscayaan. Penjelasan teoretis atas ketidakberpihakan legislatif pada sektor-sektor tersebut dapat dilihat dari konsep hubungan keagenan karena anggota parlemen memiliki kecenderungan menciptakan rente (rent creation). Mauro (1998a, 1998b) dan Tanzi \& Davoodi (2002) menemukan bahwa anggaran untuk investasi publik lebih disukai karena dapat memberikan komisi lebih besar daripada belanja untuk pelayanan sosial, pendidikan, dan kesehatan.Preferensi legislatif mengarah pada alokasi belanja yang dapat memberikan rente lebih besar. Artinya, kecenderungan legislatif untuk lebih prefer pada alokasi belanja modal merupakan realisasi dari self-interest mereka.

\section{Penelitian Terdahulu}

Penelitian sebelumnya dilakukan oleh Ikhsan Budi Riharjo dan Isnadi, (2009), "Perilaku Oportunistik Pejabat Eksekutif Dalam Penyusunan APBD (Bukti Empiris atas Penggunaan Penerimaan Sumber Daya Alam)". Hasil penelitian menunjukkan bahwa belanja pegawai langsung dan belanja modal yang ditetapkan dalam APBD berpengaruh terhadap slack anggaran untuk kemakmuran rakyat yang berasal dari pendapatan sumber daya alam. Belanja barang dan jasa yang ditetapkan dalam APBD, tidak berpengaruh terhadap slack anggaran dalam penetapan alokasi belanja untuk kemakmuran rakyat yang berasal dari pendapatan sumber daya alam, hal ini disebabkan pemerintah daerah membebankan lebih besar ke dalam pos belanja modal, yang ditunjukkan dengan data belanja modal pada 3 tahun terakhir, sebesar sekitar satu setengah kali belanja barang dan jasa. Pilihan pejabat eksekutif mengalokasikan belanja modal lebih besar karena proses realisasi pos ini, lebih banyak memberi kesempatan bagi pejabat eksekutif untuk berperilaku oportunistik. Hal ini tidak menyebabkan gagalnya pembuktian pernyataan bahwa banyak penyimpangan penggunaan keuangan pada pengadaan barang dan jasa, karena yang dimaksud belanja barang dan jasa menurut Kepres No 80 tahun 2003 adalah belanja barang, jasa dan modal yang pengadaannya menggunakan dana APBN ataupun APBD.

\section{Kerangka Penelitian \\ Perilaku Oportunistik Legislatif dalam \\ Pengalokasian Belanja}

Terjadinya misalokasi dalam anggaran belanja pemerintah terkait dengan perilaku oportunistik politisi dan aparat pemerintah. Besarnya kewenangan legislatif dalam proses penyusunan anggaran (UU 22/1999) membuka ruang bagi legislatif untuk "memaksakan" kepentingan pribadinya. Posisi legislatif sebagai pengawas bagi pelaksanaan kebijakan pemerintah daerah, dapat digunakan untuk memprioritaskan preferensinya dalam penganggaran.

Preferensi legislatif ini memiliki tiga kemungkinan konsekuensi pada belanja sektor lain, yakni:

1. Mengurangi alokasi untuk belanja lain apabila jumlah belanja secara keseluruhan tidak bertambah.

2. Tidak merubah alokasi sektor lain jika jumlah belanja bertambah; atau kombinasi keduanya, yakni alokasi untuk sektor lain berkurang walaupun jumlah belanja secara keseluruhan bertambah.

\section{Pengaruh Pendapatan Sendiri terhadap Perilaku Oportunistik Legislatif}

Secara konseptual, perubahan pendapatan akan berpengaruh terhadap belanja atau pengeluaran, namun tidak selalu seluruh tambahan pendapatan tersebut akan dialokasikan dalam belanja. Secara empiris juga ditemukan adanya flypaper effect (Moisio, 2002), yakni adanya perbedaan dalam pola pengeluaran untuk pendapatan dari effort sendiri dengan pendapatan yang diberikan pihak lain (seperti grants atau transfer).

Dari uraian diatas dapat dibuat kerangka konseptual sebagai berikut:

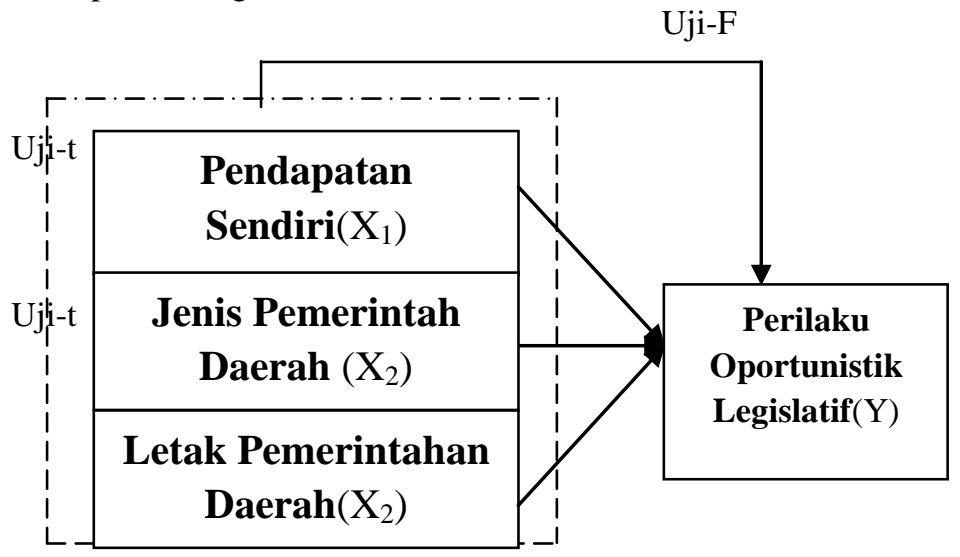

Gambar 1 Kerangka Konseptual

\section{Hipotesis Penelitian}

Berdasarkan kerangka pemikiran, maka hipotesis penelitian ini dirumuskan sebagai berikut: 
$\mathrm{H}_{1}$ : Pendapatan sendiri berpengaruh terhadap perilaku oportunistik legislatif di Dewan Perwakilan Rakyat Kabupaten (DPRK) Aceh Utara.

$\mathrm{H}_{2}$ : Jenis pemerintah daerahberpengaruh secara parsial terhadapperilaku oportunistik legislatif di Dewan Perwakilan Rakyat Kabupaten (DPRK) Aceh Utara.

$\mathrm{H}_{3}$ : $\quad$ Letak pemerintah daerahberpengaruh secara parsial terhadapperilaku oportunistik legislatif di Dewan Perwakilan Rakyat Kabupaten (DPRK) Aceh Utara.

$\mathrm{H}_{4}$ : Pendapatan sendiri, jenis pemerintah daerahdan letak pemerintah daerahberpengaruh secara simultan terhadap perilaku oportunistik legislatif di Dewan Perwakilan Rakyat Kabupaten (DPRK) Aceh Utara.

\section{METODE PENELITIAN}

Objek dan Lokasi Penelitian

Objek penelitian adalah anggota legislatif, sedangkan lokasi penelitian dilakukan pada kantorDewan Perwakilan Rakyat Kabupaten (DPRK) Aceh Utara.Penelitian ini melihat pengaruh pendapatan sendiri, jenis pemerintah daerah danletak pemerintah daerahberpengaruh secara simultan terhadap perilaku oportunistik legislatif di Dewan Perwakilan Rakyat Kabupaten (DPRK) Aceh Utara.Data dalam penelitian ini menggunakan kuesioner yang disebarkan kepada anggota legislatif Kabupaten Aceh Utara.

\section{Populasi dan Sampel Populasi}

Menurut Sugiyono (2014:80) populasi adalah wilayah generalisasi, obyek/subyek yang mempunyai kualitas dan karakteristik tertentu yang ditetapkan oleh peneliti untuk dipelajari dan kemudian ditarik kesimpulannya.Jika elemen populasi homogen artinya populasi tersebut mempunyai kriteria yang sama, sehingga tidak perlu mempersoalkan berapa banyak jumlah ukuran sampel harus diambil, penelitian terhadap seluruh elemen dalam populasi menjadi tidak masuk akal, dan apabila keadaan populasi adalah homogen, maka dapat menggunakan sampel yang lebih kecil. (Sugiyono, 2014:82). Populasi yang dipilih dalam penelitian ini adalah anggota legislatif Kabupaten Aceh Utara sebanyak 45 orang.

\section{Sampel}

Sampel adalah bagian dari jumlah dan karakteristik yang dimiliki oleh populasi tersebut (Sugiyono, 2014:83). Untuk menentukan besarnya sampel, maka perlu dipertimbangkan pendapat beberapa ahli tentang penentuan besarnya sampel. Dalam menentukan besarnya sampel terdapat perbedaan argumentasi tentang besarnya sampel penelitian yang diungkapkan oleh para pakar penelitian.
Teknik pengambilan sampel dalam penelitian ini adalah totalsampling. Total sampling adalah teknik pengambilan sampel dimanajumlah sampel sama dengan populasi (Sugiyono, 2014:85). Alasan mengambiltotal sampling karena menurut (Sugiyono, 2014:87) jumlah populasi yangkurang dari 100 seluruh populasi dijadikan sampel penelitian semuanya.Dalam penentuan jumlah sampel pada penelitian ini sesuai dengan jumlah populasi yaitu 45 responden untuk anggota legislatif. Adapun nama anggota dewan, nama partai dan daerah pemilihan seperti dibawah ini :

Tabel 1

Nama-Nama Anggota DPRK Aceh Utara

\begin{tabular}{|c|c|c|c|}
\hline No & $\begin{array}{c}\text { Nama Anggota } \\
\text { Dewan }\end{array}$ & Nama Partai & $\begin{array}{c}\text { Daerah } \\
\text { Pemilihan } \\
\end{array}$ \\
\hline 1 & Tgk. Junaidi & \multirow{24}{*}{ Partai Aceh } & \multirow{4}{*}{ Dapil I } \\
\hline 2 & Fauzi & & \\
\hline 3 & M. Dahlan Ilyas & & \\
\hline 4 & Mukhtar & & \\
\hline 5 & Sulaiman & & \multirow{5}{*}{ Dapil II } \\
\hline 6 & Supianuddin & & \\
\hline 7 & Arafat & & \\
\hline 8 & $\begin{array}{l}\text { Tgk. Fauzan } \\
\text { Hamzah, SHi }\end{array}$ & & \\
\hline 9 & Nurdin Hasbi & & \\
\hline 10 & $\begin{array}{l}\text { Abdul Mutaleb, } \\
\text { S.Sos }\end{array}$ & & \multirow{3}{*}{ Dapil III } \\
\hline 11 & $\begin{array}{l}\text { Tgk. Abdullah } \\
\text { Ben Yunus }\end{array}$ & & \\
\hline 12 & $\begin{array}{l}\text { Tgk. } \\
\text { Maimunsyah }\end{array}$ & & \\
\hline 13 & Saifuddin & & \multirow{3}{*}{ Dapil IV } \\
\hline 14 & Riyanti & & \\
\hline 15 & $\begin{array}{l}\text { Tgk. Muhammad } \\
\text { Nasir }\end{array}$ & & \\
\hline 16 & Ismail Arahman & & \multirow{4}{*}{ Dapil V } \\
\hline 17 & Mawardi & & \\
\hline 18 & Samsuddin JS & & \\
\hline 19 & Syahril Indra & & \\
\hline 20 & Ismail A Jalil, SE & & \multirow{8}{*}{ Dapil VI } \\
\hline 21 & Syarwani & & \\
\hline 22 & Muhammad Nasir & & \\
\hline 23 & Drs. Ismail Kamil & & \\
\hline 24 & Jamaluddin Jalil & & \\
\hline 25 & $\begin{array}{l}\text { Tgk. H Saifannur } \\
\text { H. Cut }\end{array}$ & \multirow{3}{*}{$\begin{array}{l}\text { Partai Persatuan } \\
\text { Pembangunan }\end{array}$} & \\
\hline 26 & $\begin{array}{l}\text { Zainuddin Iba, } \\
\text { SE, MM, }\end{array}$ & & \\
\hline 27 & $\begin{array}{l}\text { Zulfadhli } \\
\text { Taleb, SE, }\end{array}$ & & \\
\hline
\end{tabular}




\begin{tabular}{|c|c|c|}
\hline 28 & $\begin{array}{l}\text { Tgk. Marhaban } \\
\text { Habibi,S.Pd.I }\end{array}$ & \\
\hline 29 & $\begin{array}{l}\text { H. Ismed Nur Aj. } \\
\text { Hasan, S.Sos }\end{array}$ & \\
\hline 30 & H. Mulyadi CH & \\
\hline 31 & Saiful, A.Md & \multirow{5}{*}{ Partai Nasdem } \\
\hline 32 & Anzir, SH & \\
\hline 33 & H. Saifuddin, SH & \\
\hline 34 & Iskandar & \\
\hline 35 & T. Bakhtiar & \\
\hline 36 & M. Sani Ishak & \multirow{3}{*}{$\begin{array}{l}\text { Partai Amanat } \\
\text { Nasional }\end{array}$} \\
\hline 37 & Saifullah & \\
\hline 38 & Hasanusi & \\
\hline 39 & H. Hasanuddin & \multirow[b]{2}{*}{ Partai Golkar } \\
\hline 40 & Drs. As'adi & \\
\hline 41 & Sofiyan Hanafiah & \multirow[b]{2}{*}{$\begin{array}{c}\text { Partai Nanggroe } \\
\text { Aceh }\end{array}$} \\
\hline 42 & $\begin{array}{l}\text { Misbahul Munir, } \\
\text { ST }\end{array}$ & \\
\hline 43 & Muhammad Waly & $\begin{array}{c}\text { Partai } \\
\text { Kebangkitan } \\
\text { Bangsa } \\
\end{array}$ \\
\hline 44 & Tantawi, A.Md. & Partai Demokrat \\
\hline 45 & H. Anwar Risyen. & Partai Gerindra \\
\hline
\end{tabular}

Sumber : KIP Kabupaten Aceh Utara, (2018)

\section{Jenis, Sumber danTeknik Pengumpulan Data}

Jenis data yang digunakan dalam penelitian ini adalah data subjek. Sumber data dalam penelitian ini adalah data primer. Data untuk penelitian ini dikumpulkan dengan cara menyebarkan kuesioner kepada populasi dalam penelitian ini.Metode pengumpulan data dalam penelitian ini dilakukan dengan cara memberikan seperangkat pertanyaan atau pertanyaan tertulis kepada responden agar dijawabnya (Sugiyono, 2012:199). Data yang diambil tersebut berupa data primer. Data primer diperoleh melalui penyebaran kuisioner ke Dewan Perwakilan Rakyat Kabupaten (DPRK) Aceh Utara.Kuesioner dalam penelitian ini dibuat dalam bentuk skala likert. Setiap pernyataan disediakan 5 (lima) alternatif jawaban yang memiliki skor 1-5, yaitu Sangat Setuju (SS), dan Setuju (S), Kurang Setuju (KS), Tidak Setuju (TS), dan Sangat Tidak Setuju (STS).

\section{Definisi Operasional Variabel}

Sesuai dengan judul penelitian terdapat tiga variabel yang akan diteliti dalam penelitian ini, variabel ini dibagi dalam bentuk variabel independen dan variabel dependen, diantaranya adalah pendapatan sendiri, jenis pemerintah daerah danletak pemerintah daerah danperilaku oportunistik legislatif.

\section{Uji Validitas dan Reliabilitas Uji Validitas}

Untuk mengetahui instrumen yang dipakai cukup layak digunakan sehingga menghasilkan data yang akurat, maka dilakukan uji validitas. Validitas adalah suatu ukuran yang menunjukkan tingkat kesahihan suatu instrumen. Instrumen yang sahih atau valid berarti memiliki validitas tinggi, demikian pula sebaliknya. Sebuah instrumen dikatakan sahih, apabila mampu mengukur apa yang diinginkan atau mengungkap data dari variabel yang diteliti secara tepat. Singarimbun dan Effendi (2005:141) mengatakan bahwa "Uji validitas dilakukan dengan melihat korelasi product moment $\left(\mathrm{r}_{\text {hitung }}\right.$ ), apabila korelasi tiap item pertanyaan >critical value $\left(\mathrm{r}_{\text {tabel }}\right)$ maka item tersebut dinyatakan valid (sahih)".

\section{Uji Reliabilitas}

Uji reliabilitas untuk mengukur suatu kuesioner yang merupakan indikator dari variabel atau konstruk. Suatu kuesioner dikatakan reliabel atau handal jika jawaban seseorang terhadap pernyataan adalah konsisten dan stabil dari waktu kewaktu. Pengukuran reliabilitas dapat dilakukan dengan one shot atau pengukuran sekali saja (Ghozali, 2005). Suatu kontruk atau variabel dikatakan reliabel apabila nilai Cronbach Alpha $(\alpha)>0,60$ (Nunnally dalam Ghozali, 2005).

\section{Uji Asumsi Klasik \\ Uji Normalitas}

Uji normalitas bertujuan untuk mengetahui apakah dalam model regresi, variabel terikat dan variabel bebas memiliki distribusi yang normal atau tidak, karena model regresi yang baik memiliki distribusi data yang normal atau mendekati normal. Pembuktian apakah data tersebut memiliki distribusi normal atau tidak dapat dilihat pada bentuk distribusi datanya, yaitu pada histogram maupun normal probability plot. Pada histogram, data dikatakan memiliki distribusi yang normal jika data tersebut berbentuk seperti lonceng. Sedangkan pada normal probability plot, data dikatakan normal jika ada penyebaran titik-titik disekitar garis diagonal dan penyebarannya mengikuti arah garis diagonal. Ghozali (2005:89) menyebutkan jika data menyebar disekitar garis diagonal dan mengikuti arah garis diagonal maka model regresi memenuhi asumsi normalitas.

\section{Uji Multikolinieritas}

Pengujian ini dilakukan untuk menunjukkan adanya hubungan linier antara variabel-variabel bebas dalam model regresi.Model regresi yang baik tidak menghendaki adanya masalah multikolinieritas ini.Uji multikolinieritas menggunakan nilai tolerance dan Variance Inflation Factor (VIF). Kedua ukuran ini menunjukkan setiap variabel bebas manakah yang 
dijelaskan oleh variabel bebas lainnya. Dalam pengertian sederhana setiap variabel bebas menjadi variabel terikat dan diregresi terhadap variabel bebas lainnya. Tolerance mengukur variabilitas variabel bebas yang terpilih yang tidak dapat dijelaskan oleh variabel bebas lainnya. Jadi nilai tolerance yang rendah sama dengan nilai VIF tinggi (karena VIF $=1 /$ tolerance ) dan menunjukkan adanya kolonieritas yang tinggi. Lebih ditegaskan oleh Ghozali bila korelasi antara dua variabel bebas melebihi $95 \%$ maka VIF-nya diatas 5 maka dapat dikatakan bahwa model tersebut terkena multikolinieritas (Ghozali,2005:63).

\section{Uji Heterokedastisitas}

Tujuan pengujian ini adalah untuk mengetahui apakah dalam model regresi terjadi ketidaksamaan variance dari residual satu pengamatan ke pengamatan yang lain. Jika variance dari residual satu pengamatan ke pengamatan yang lain tetap maka disebut homokedastisitas, namun jika berbeda disebut dengan heterokedastisitas. Untuk mendeteksi ada atau tidaknya heteroskedastisitas dilakukan dengan cara melihat grafik. Menurut Ghozali (2005:105) jika tidak ada pola yang jelas, serta titik-titik menyebar di atas dan di bawah angka 0 pada sumbu $\mathrm{Y}$, maka tidak terjadi heteroskedastisitas.

\section{Teknik Analisis Data}

Analisis regresi berganda digunakan sebagai alat untuk mengukur seberapa besar pengaruh antara variabel independen $(\mathrm{X})$ dengan variabel dependen (Y).metode ini juga bisa dijadikan ramalan, sehingga dapat diperkirakan antara baik dan buruknya suatu variabel (X) terhadap turunnya tingkat variabel $(\mathrm{Y})$, begitu juga sebaliknya. Analisis regresi ini mempunyai persamaan sebagai berikut:

Keterangan:

$$
\mathbf{Y}=\mathbf{a}+\mathbf{b}_{1} \mathbf{X}_{1}+\mathbf{b}_{2} \mathbf{X}_{2}+\mathbf{b}_{3} \mathbf{X}_{3}+\grave{\mathbf{e}}
$$

$$
\begin{array}{ll}
\mathrm{Y} & =\text { Perilaku Oportunistik Legislatif } \\
\mathrm{X}_{1} & =\text { Pendapatan Sendiri } \\
\mathrm{X}_{2} & =\text { Jenis Pemerintah Daerah } \\
\mathrm{X}_{3} & =\text { Letak Pemerintah Daerah } \\
\mathrm{a} & =\text { Konstanta } \\
\mathrm{b} 1 & =\text { Nilai koefisien regresi berganda }
\end{array}
$$

antara variabel independen $\mathrm{X} 1$ terhadap variabel dependen $\mathrm{Y}$, bila variabel independen X2 dianggap konstan

b2 = Nilai koefisien regresi berganda antara variabel independen X2

terhadap variabel dependen $\mathrm{Y}$, bila variabel independen X1

dianggap konstan

b3 = Nilai koefisien regresi berganda antara variabel independen X2

terhadap variabel dependen $\mathrm{Y}$, bila variabel independen X1

dianggap konstan

è $\quad=$ error term yaitu faktor-faktor lain

yang mempengaruhi variabel

dependen $\mathrm{Y}$

\section{Koefisien Determinasi $\left(\mathbf{R}^{2}\right)$}

Koefisien determinasi $\left(\mathrm{R}^{2}\right)$ dimaksudkan untuk mengetahui tingkat ketepatan paling baik dalam analisa regresi dimana hal yang ditunjukan oleh besarnya koefisien determinasi $\left(\mathrm{R}^{2}\right)$ antara 0 (nol) dan 1 (satu). Koefsien determinasi $\left(\left(\mathrm{R}^{2}\right)\right.$ nol variabel independen sama sekali tidak berpengaruh terhadap variabel dependen.Apabila koefisien determinasi semakin mendekati satu, maka dapat dikatakan bahwa variabel independen berpengaruh terhadap variabel dependen, Selain itu koefisien determinasi $\left(\mathrm{R}^{2}\right)$ dipergunakan untuk mengetahui prosentase perubahan variabel tidak bebas (Y) yang disebabkan oleh variabel bebas $(\mathrm{X})$.

\section{Pengujian Hipotesis \\ Uji-t (Uji Parsial)}

Uji-t dilakukan untuk mengetahui apakah ada pengaruh variabel independen secara parsial yaitu pendapatan sendiri, jenis pemerintah daerahdan letak pemerintah daerah terhadap variabel dependen yaitu perilaku oportunistik legislatifdengan tingkat kepercayaan $95 \%(\alpha=5 \%)$. Pengujian ini dilakukan dengan membandingkan hasil perhitungan $t_{\text {hitung }}$ dengan $\mathrm{t}_{\text {tabel }}$ pada taraf signifikan 0,05 . Apabila kriteria hasil perhitungan menunjukkan:

1. Jika $t_{\text {hitung }}>t_{\text {tabel }}$, maka menolak $H_{o}$ dan menerima $\mathrm{H}_{1}$,yang berarti pendapatan sendiri, jenis pemerintah daerahdanletak pemerintah daerah secara parsial berpengaruh signifikan terhadap variabel dependen yaitu perilaku oportunistik legislatif.

2. Jika $t_{\text {hitung }}<t_{\text {tabel }}$, maka menerima $H_{o}$ dan menolak $\mathrm{H}_{1}$, yang berarti pendapatan sendiri, jenis pemerintah daerahdanletak pemerintah daerah secara parsial tidak berpengaruh signifikan terhadap variabel dependen yaitu perilaku oportunistik legislatif.

\section{Uji-F (Uji Simultan)}

Uji-F dilakukan untuk mengetahui apakah ada pengaruh variabel independen secara simultan yaitu pendapatan sendiri, jenis pemerintah daerahdanletak pemerintah daerah terhadap variabel dependen yaitu perilaku oportunistik legislatif dengan tingkat kepercayaan $95 \% \quad(\alpha=5 \%)$. Pengujian uji-F adalah dengan membandingkan $\mathrm{F}_{\text {hitung }}$ dengan $\mathrm{F}_{\text {tabel }}$ pada probabilitas 0,05 apabila kriteria pengambilan keputusan menunjukkan:

1. Jika $F_{\text {hitung }}>F_{\text {tabel }}$, maka menolak $H_{o}$ dan menerima $\mathrm{H}_{1}$, yang berartipendapatan sendiri, jenis pemerintah daerahdanletak pemerintah daerah secara bersama-sama (simultan) berpengaruh signifikan perilaku oportunistik legislatif.

2. Jika $F_{\text {hitung }}<\mathrm{F}_{\text {tabel }}$, maka menerima $\mathrm{H}_{\mathrm{o}}$ dan menolak $\mathrm{H}_{1}$, yang berartipendapatan sendiri, jenis pemerintah daerahdanletak pemerintah daerah secara bersama-sama 
(simultan) tidak berpengaruh signifikan Terhadap perilaku oportunistik legislatif.

\section{HASIL DAN PEMBAHASAN}

\section{Uji Validitas}

Uji validitas digunakan untuk mengukur sah atau valid tidaknya suatu kuesioner. Adapun kriteria pengambilan keputusan uji validitas instrument dalam penelitian ini adalah membandingkan nilai Corrected Item-TotalCorrelation pada setiap butir pertayaan dengan nilai $\mathrm{r}$ tabel. Jika nilai Corrected ItemTotalCorrelation $\left(\mathrm{r}_{\text {hitung }}\right)>\mathrm{r}_{\text {tabel }}$ dan nilainya positif, maka butir pertanyaan pada setiap variabel tersebut dinyatakan valid. Sebalikya jika Corrected ItemTotalCorrelation $\left(\mathrm{r}_{\text {hitung }}\right)<\mathrm{r}_{\text {tabel }}$ dan nilainya negatif, maka pertanyaan pada setiap variabel tersebut dinyatakan tidak valid, hasilnya pada tabel 4.7. dibawah ini:

Tabel 2

Hasil Pengujian Validitas

\begin{tabular}{|c|c|c|c|c|}
\hline No & $\begin{array}{l}\text { Indikator } \\
\text { Pertanyaan }\end{array}$ & $\begin{array}{c}\text { Correcte } \\
\text { d Item- } \\
\text { Total } \\
\text { Correlati } \\
\text { on } \\
/ \mathbf{r}_{\text {hitung }}\end{array}$ & $\mathbf{r}_{\text {tabel }}$ & $\begin{array}{c}\text { Ketera } \\
\text { ngan }\end{array}$ \\
\hline 1. & $\begin{array}{l}\text { Pendapatan Sendiri } \\
\text { - P1 } \\
\text { - P2 } \\
\text { - P3 }\end{array}$ & $\begin{array}{l}0,565 \\
0,432 \\
0,412\end{array}$ & $\begin{array}{l}0.308 \\
0.308 \\
0.308\end{array}$ & $\begin{array}{l}\text { Valid } \\
\text { Valid } \\
\text { Valid }\end{array}$ \\
\hline 2. & $\begin{array}{l}\text { Jenis Pemerintahan } \\
\text { Daerah } \\
\text { - P4 } \\
\text { - P5 } \\
\text { - P6 }\end{array}$ & $\begin{array}{l}0,354 \\
0,425 \\
0,454\end{array}$ & $\begin{array}{l}0.308 \\
0.308 \\
0.308\end{array}$ & $\begin{array}{l}\text { Valid } \\
\text { Valid } \\
\text { Valid }\end{array}$ \\
\hline 3 & $\begin{array}{l}\text { Letak } \\
\text { Pemerintahan } \\
\text { Daerah } \\
\text { - P7 } \\
\text { - P8 } \\
\text { - P9 }\end{array}$ & $\begin{array}{l}0,425 \\
0,322 \\
0,432\end{array}$ & $\begin{array}{l}0.308 \\
0.308 \\
0.308\end{array}$ & $\begin{array}{l}\text { Valid } \\
\text { Valid } \\
\text { Valid }\end{array}$ \\
\hline 4. & $\begin{array}{l}\text { Perilaku } \\
\text { Oportunitis } \\
\text { Legislatif } \\
\text { - P10 } \\
\text { - P11 } \\
\text { - P12 }\end{array}$ & $\begin{array}{l}0,413 \\
0,322 \\
0,453\end{array}$ & $\begin{array}{l}0.308 \\
0.308 \\
0.308\end{array}$ & $\begin{array}{l}\text { Valid } \\
\text { Valid } \\
\text { Valid }\end{array}$ \\
\hline
\end{tabular}

Sumber: Hasil Penelitian, Data diolah (Januari, 2019).

Berdasarkan Tabel 2 dapat diketahui bahwa seluruh butir pernyataan adalah valid karena $r_{\text {hitung }}>$ $r_{\text {tabel }}$. Nilai $r_{\text {tabel }}$ dilihat pada $\mathrm{df}=45-3=41$ sebesar 0.308 . Dari hasil tersebut menunjukkan bahwa masing-masing pertanyaan adalah valid.

\section{Uji Reliabilitas}

Uji reliabilitas adalah alat untuk mengukur suatu kuesioner yang merupakan indikator dari variabel atau konstruk. Suatu kuesioner dikatakan reliabel atau handal jika jawaban seseorang terhadap pernyataan adalah konsisten atau stabil dari waktu ke waktu. Pengukuran reliabilitas dapat dilakukan dengan one shot atau pengukuran sekali saja (Ghozali, 2005:42). Suatu kontruk atau variabel dikatakan reliabel, apabila (Nunally dalam Ghozali, 2005:43):

1. Hasil Alpha Cronbach $(\alpha)>0,60=$ reliabel

2. Hasil Alpha Cronbach $(\alpha)<0,60=$ tidak reliabel.

Adapun secara ringkas hasil uji reliabilitas ditunjukkan dalam Tabel 4.8 berikut ini:

\section{Tabel 3}

Hasil Pengujian Reliabilitas

\begin{tabular}{|c|c|}
\hline $\begin{array}{c}\text { Cronbach's } \\
\text { Alpha }\end{array}$ & Jumlah Pertanyaan \\
\hline 0,853 & 12 \\
\hline
\end{tabular}

Sumber: Hasil Penelitian, Data diolah (Januari, 2019).

Berdasarkan Tabel 4.8 diatas, dapat diketahui bahwa dari ke 12 (Dua Belas) pertanyaan nilai cronbach's alpha> 0.6, dengan demikian pengukuran reliabilitas menunjukkan bahwa ke 12 pernyataan tersebut telah reliabel dan dapat disebarkan kepada responden untuk dijadikan sebagai instrumen penelitian.

\section{Uji Asumsi Klasik}

\section{Uji Normalitas Data}

Uji normalitas bertujuan untuk menguji apakah dalam model regresi variabel pengganggu atau residual memiliki distribusi normal. Untuk melihat normalitas residual dapat dilakukan dengan análisis grafik normal probability plot (PP-Plot) of regression standarized residual yang membandingkan distribusi komulatif dari distribusi normal. Distribusi normal akan membentuk satu garis lurus diagonal, dan ploting data residual akan dibandingkan dengan garis lurus diagonal.

Gambar dibawah ini:

Hasil pengujian normalitas dapat dilihat pada Normal P-P Plot of Regression Standardized

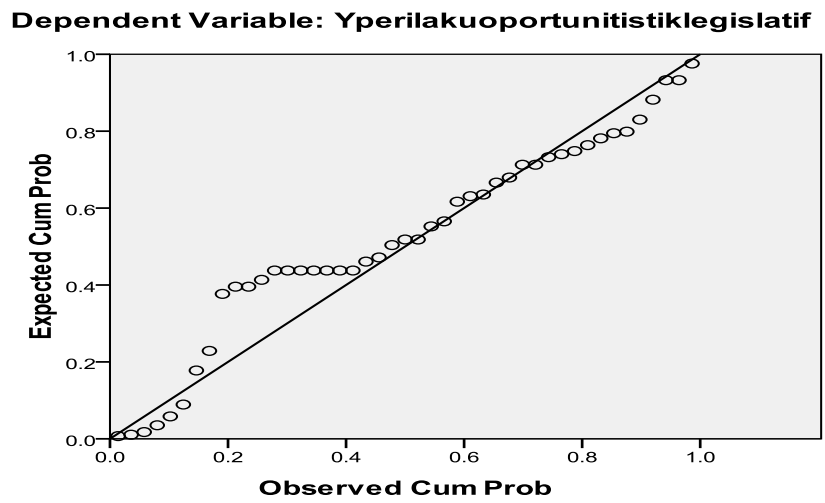

Gambar 2 Uji Normalitas P-P Plot

Sumber: Hasil Penelitian, Data diolah (Januari, 2019).

Berdasarkan Gambar diatas, menunjukkan bahwa titik-titik residual model regresi sudah berdistribusi normal karena titik-titik tersebut menyebar di sekitar garis diagonal. Dengan demikian, syarat kenormalan sebagai pengujian statistik dengan menggunakan regresi dapat terpenuhi. 


\section{Uji Multikolinieritas}

Uji multikolinieritas bertujuan untuk menguji apakah terdapat korelasi yang sempurna diantara beberapa variabel bebas yang digunakan dalam persamaan regresi digunakan uji multikolinieritas. Uji multikolinieritas menggunakan nilai tolerance dan VIF (varian Inflation Factor). Hasil pengujian multikolinieritas dapat dilihat pada Tabel 4.9 dibawah ini:

Tabel 4

Uji Multikolinieritas

Coefficients $^{a}$

\begin{tabular}{|c|c|c|c|c|c|c|c|}
\hline \multirow[b]{2}{*}{ Model } & \multicolumn{2}{|c|}{$\begin{array}{c}\text { Unstandardi } \\
\text { zed } \\
\text { Coefficients }\end{array}$} & \multirow{2}{*}{\begin{tabular}{|c|}
$\begin{array}{c}\text { tanda } \\
\text { rdized } \\
\text { Coeffici } \\
\text { ents }\end{array}$ \\
Beta \\
\end{tabular}} & \multirow[b]{2}{*}{$\mathrm{t}$} & \multicolumn{3}{|c|}{$\begin{array}{c}\text { Collinearit } \\
y \\
\text { Statistics }\end{array}$} \\
\hline & B & $\begin{array}{l}\text { Std. } \\
\text { Error }\end{array}$ & & & $\begin{array}{l}\mathrm{Si} \\
\mathrm{g} .\end{array}$ & $\begin{array}{l}\text { Toler } \\
\text { ance }\end{array}$ & VIF \\
\hline 1 (Constant) & 4.383 & $\begin{array}{r}2.86 \\
9\end{array}$ & & $\begin{array}{r}1.5 \\
28\end{array}$ & $\begin{array}{r}.1 \\
3 \\
4 \\
\end{array}$ & & \\
\hline $\begin{array}{l}\text { X1pendapatan } \\
\text { sendiri }\end{array}$ & .115 & 221 & .076 & $\begin{array}{r}.52 \\
1\end{array}$ & $\begin{array}{r}.6 \\
0 \\
5\end{array}$ & $94^{.8}$ & $\begin{array}{r}1 \\
, 11 \\
9\end{array}$ \\
\hline $\begin{array}{l}\text { X2jenispemeri } \\
\text { ntahandaerah }\end{array}$ & .130 & .170 & .122 & $\begin{array}{r}.76 \\
5\end{array}$ & $\begin{array}{r}.4 \\
8 \\
8\end{array}$ & $45^{.7}$ & $\begin{array}{r}1 \\
34 \\
3\end{array}$ \\
\hline $\begin{array}{l}\text { X3letakpemeri } \\
\text { ntahandaerah }\end{array}$ & .405 & 169 & .373 & $\begin{array}{r}2.4 \\
01\end{array}$ & $\begin{array}{r}.0 \\
2 \\
1\end{array}$ & $89^{.7}$ & $\begin{array}{l}1,2 \\
67\end{array}$ \\
\hline
\end{tabular}

a. Dependent Variable: Yperilakuoportunistiklegislatif

Sumber: Hasil Penelitian, Data diolah (Januari, 2019).

Berdasarkan Tabel menunjukkan bahwa variabel pendapatan sendiri, jenis pemerintahan daerah dan letak pemerintahan daerah yang digunakan sebagai prediktor model regresi menunjukkan nilai VIF yang cukup kecil, dimana semuanya berada di bawah 10 dan tolerance > 0.1, hal ini menandakan bahwa model regresi yang dihasilkan tidak terjadi multikolinieritas dan baik untuk digunakan.

\section{Uji Heteroskedastisitas}

Uji Heteroskedastisitas bertujuan menguji apakah dalam model regresi terjadi ketidaksamaan variance dari residual suatu pengamatan ke pengamatan yang lain. Jika variance dari residual satu pengamatan kepengamatan lain tetap disebut homokedastisitas dan jika berbeda disebut heteroskedastisitas. Untuk mendeteksi ada atau tidaknya heteroskedastisitas dilakukan dengan cara scanelibibat grafik. Pengujian heteroskedastisitas dapat dilihat pada Gambar 4.2 dibawah ini:

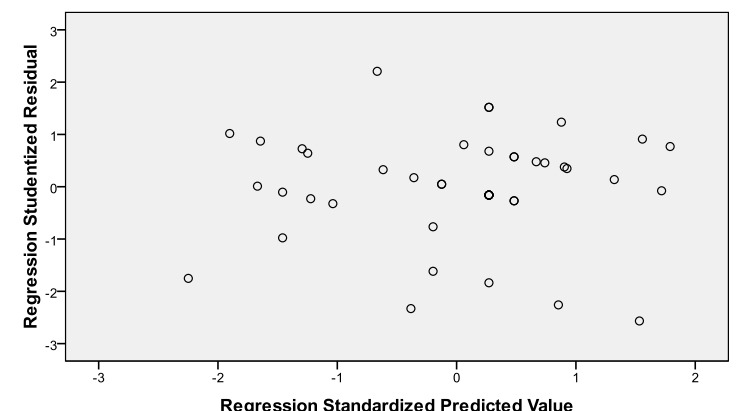

Gambar 4.2 Uji Heteroskedastisitas

Sumber: Hasil Penelitian, Data diolah (Januari, 2019).

Berdasarkan Gambar diatas dapat dilihat bahwa titik-titik data menyebar di atas dan dibawah atau sekitar angka 0 pada sumbu $\mathrm{Y}$, maka berdasarkan metode grafik tidak terjadi heteroskedastisitas pada model regresi.

\section{Pembahasan}

\section{Hasil Regresi Linier Berganda}

Penelitian ini mengenai tentang pengaruh pendapatan sendiri, jenis pemerintahan daerah dan letak pemerintahan daerah terhadap perilaku oportunistik anggota legislatifdi DPRK Aceh Utara. Hasil analisis dengan menggunakan model regresi linier berganda yang telah memenuhi uji normalitas antara variabel pendapatan sendiri $\left(\mathrm{X}_{1}\right)$ jenis pemerintahan daerah $\left(\mathrm{X}_{2}\right)$, letak pemerintahan daerah $\left(\mathrm{X}_{3}\right)$ dan perilaku oportunistik legislatifdi DPRK Aceh Utara(Y), dapat dilihat pada tabel 4.10 dibawah ini:

Tabel 4

Hasil Regresi Linier Berganda Coefficients $^{\mathrm{a}}$

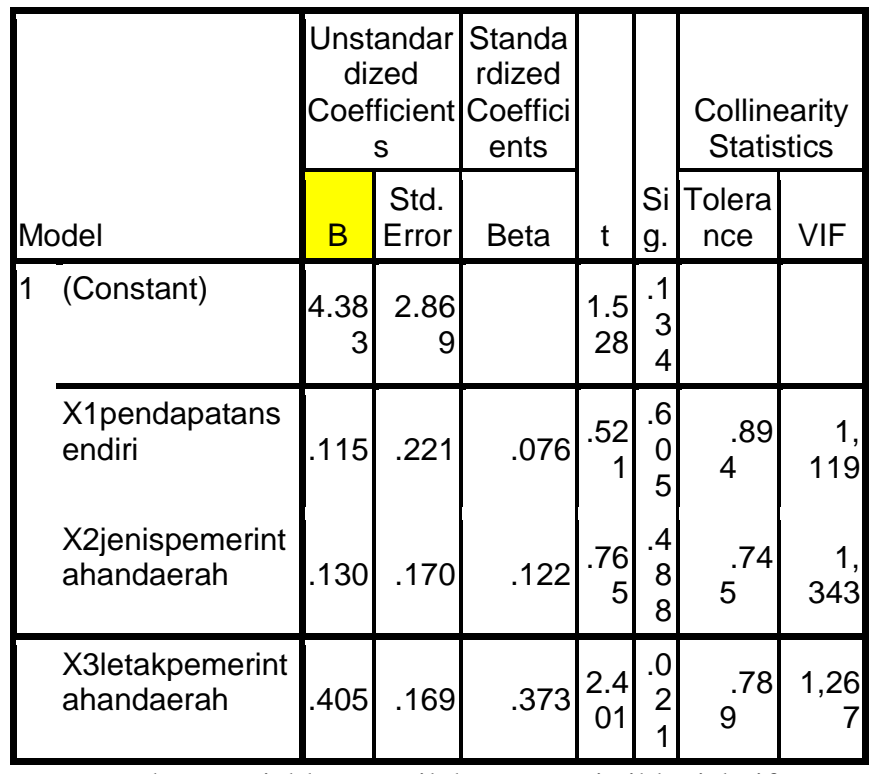

a. Dependent Variable: Yperilakuoportunistiklegislatif

Sumber: Hasil Penelitian, Data diolah (Januari, 2019).

Berdasarkan hasil pengolahan data seperti terlihat pada Tabel 4.10, Kolom unstandardized Coefficients bagian B diperoleh persamaan regresi linier Berganda sebagai berikut:

$$
\begin{aligned}
& Y=a+b_{1} X_{1+} b_{2} X_{2+} b_{3} X_{3}+e \\
& Y=4,383+0,115 X_{1}+0,130 X_{2}+0,405 X_{3} \\
& \text { Berdasarkan persamaan tersebut dapat }
\end{aligned}
$$
dianalisiskan sebagai berikut:

a. Konstanta (a) $=\mathbf{4 , 3 8 3}$, ini mempunyai arti bahwa variabel pendapatan sendiri, jenis pemerintahan daerah dan letak pemerintahan 
daerahterhadap perilaku oportunistik legislatif(Y) memiliki hubungan positif sebesar 4,383. Diinterprestasikan apabila variabel pendapatan sendiri $\left(\mathrm{X}_{1}\right)$, jenis pemerintahan daerah $\left(\mathrm{X}_{2}\right)$, dan letak pemerintahan daerahsama dengan 0 maka perilaku oportunistik legislatifdi DPRK Aceh Utara akan tetap sebesar 4,383.

b. Nilai Koefisien $X_{1}\left(b_{1}\right)=\mathbf{0 , 1 1 5}$, pengaruh variabel pendapatan sendiri terhadap perilaku oportunistik legislatifmemiliki hubungan positif sebesar 0,115. Diinterprestasikan jika nilai pendapatan sendiri meningkat sebesar $1 \%$, maka perilaku oportunistik legislatifdi DPRK Aceh Utara akan meningkat sebesar 0,115 (dengan asumsi pendapatan sendiri dianggap konstan).

c. Nilai Koefisien $\mathbf{X}_{2}\left(\mathbf{b}_{2}\right)=\mathbf{0 , 1 3 0}$,pengaruh variabel jenis pemerintahan daerah terhadap perilaku oportunistik legislatifmemiliki hubungan positif sebesar 0,130. Diinterprestasikan jika nilai jenis pemerintahan daerah meningkat sebesar $1 \%$, maka perilaku oportunistik legislatifdi DPRK Aceh Utara akan meningkat sebesar 0,130 (dengan asumsi jenis pemerintahan daerah dianggap konstan).

d. Nilai Koefisien $\mathbf{X}_{\mathbf{3}}\left(\mathbf{b}_{\mathbf{3}}\right)=\mathbf{0 , 4 0 5}$,pengaruh variabel letak pemerintahan daerah terhadap perilaku oportunistik legislatifmemiliki hubungan positif sebesar 0,405. Diinterprestasikan jika nilai letak pemerintahan daerah meningkat sebesar $1 \%$, maka perilaku oportunistik legislatifdi DPRK Aceh Utara akan meningkat sebesar 0,405 (dengan asumsi letak pemerintahan daerah dianggap konstan).

\section{Koefisien Determinasi $\left(\boldsymbol{R}^{2}\right)$}

Koefisien determinasi pada regresi linear sering diartikan sebagai seberapa besar kemampuan semua variabel bebas dalam menjelaskan varians dari variabel terikatnya. Secara sederhana koefisien determinasi dihitung dengan mengkuadratkan Koefisien Korelasi (R). Koefisien determinasi ini digunakan untuk mengetahui seberapa besar pengaruh variabel-variabel bebas memiliki pengaruh terhadap variabel terikatnya. Nilai koefisien determinasi ditentukan dengan nilai adjusted $R$ square. Dalam output SPSS, koefisien determinasi terletak pada tabel Model Summary ${ }^{b}$. Untuk hasil koefisien korelasi dan determinasi dapat dilihat pada Tabel 4.11 dibawah ini:

\section{Tabel 6}

Hasil Koefisien Korelasi dan Determinasi a Predictors: (Constant), pendapatan sendiri, jenis pemerintahan daerah dan letak pemerintahan daerah b Dependent Variable: perilaku oportunistik legislatif Sumber: Hasil Penelitian, Data diolah (Januari, 2019).

Berdasarkan Tabel 4.11 di atas, koefisien korelasi (R) sebesar 0,468 atau 46,8\% yang bermakna eratnya hubungan (korelasi) antara pendapatan sendiri, jenis pemerintahan daerah dan letak pemerintahan daerah dengan perilaku oportunistik legislatif di DPRK Aceh Utara artinya hubungan antara pendapatan sendiri, jenis pemerintahan daerah dan letak pemerintahan daerah terhadap perilaku oportunistik legislatifsebesar
0,468. Sedangkan koefisien determinasi $(R$ Square)sebesar 0,219 atau $21,9 \%$, artinya variabel pendapatan sendiri, jenis pemerintahan daerah dan letak pemerintahan daerah mampu memengaruhi perilaku oportunistik legislatifsebesar 21,9\%, sedangkan selebihnya $88,1 \%$ perilaku oportunistik legislatif dipengaruhi oleh variabel-variabel lainnya yang tidak dimasukkan dalam penelitian ini.

\section{Pembuktian Hipotesis}

Uji t dilakukan untuk menguji secara parsial variabel bebas atau independen yang terdiri dari variabel pendapatan sendiri $\left(\mathrm{X}_{1}\right)$, jenis pemerintahan daerah $\left(\mathrm{X}_{2}\right)$, letak pemerintahan daerah dan yang menjadi variabel terikat atau dependen yaitu perilaku oportunistik legislatifdi Dewan Perwakilan Rakyat Kabupaten (DPRK) Aceh Utara.(Y). Hasil uji-t dapat dilihat pada Tabel dibawah ini:

Tabel 7

Hasil Pengujian Secara Parsial (Uji-t) Coefficients $^{a}$

\begin{tabular}{|c|c|c|c|c|c|c|c|}
\hline \multirow[b]{2}{*}{ Model } & \multicolumn{2}{|c|}{$\begin{array}{c}\text { Unstandar } \\
\text { dized } \\
\text { Coefficient } \\
\text { s }\end{array}$} & \multirow{2}{*}{\begin{tabular}{|c|}
$\begin{array}{c}\text { Standar } \\
\text { dized } \\
\text { Coeffici } \\
\text { ents }\end{array}$ \\
Beta \\
\end{tabular}} & \multirow[b]{2}{*}{$\mathrm{t}$} & \multirow[b]{2}{*}{$\begin{array}{l}\mathrm{Si} \\
\mathrm{g} .\end{array}$} & \multicolumn{2}{|c|}{$\begin{array}{c}\text { Collinearit } \\
y \\
\text { Statistics }\end{array}$} \\
\hline & B & $\begin{array}{l}\text { Std. } \\
\text { Error }\end{array}$ & & & & $\begin{array}{c}\text { Tolera } \\
\text { nce }\end{array}$ & $\begin{array}{l}\text { VI } \\
\text { F }\end{array}$ \\
\hline 1 (Constant) & $\begin{array}{r}4.38 \\
3\end{array}$ & 2.869 & & $\begin{array}{r}1.5 \\
28\end{array}$ & $\begin{array}{r}.1 \\
34\end{array}$ & & \\
\hline $\begin{array}{l}\text { X1pendapatanse } \\
\text { ndiri }\end{array}$ & .115 & .221 & .076 & $\begin{array}{r}.52 \\
1\end{array}$ & .6 & $\begin{array}{l}.89 \\
4\end{array}$ & $\begin{array}{r}1 \\
19\end{array}$ \\
\hline
\end{tabular}

\begin{tabular}{|c|c|c|c|c|c|c|c|}
\hline Model & $\mathrm{R}$ & & $\begin{array}{l}\text { R } \\
\text { lare }\end{array}$ & $\begin{array}{l}\text { Adjusted } \\
\text { R } \\
\text { Square }\end{array}$ & & $\begin{array}{l}\text { Sto } \\
\text { Error } \\
\text { the } \\
\text { Estim }\end{array}$ & \\
\hline 1 & $.468(a)$ & & .219 & .164 & & 1210 & \\
\hline \multicolumn{2}{|c|}{$\begin{array}{l}\text { X2jenispemerintal } \\
\text { handaerah }\end{array}$} & .130 & .170 & .122 & & $\begin{array}{r}.4 \\
88\end{array}$ & $\begin{array}{l}.74 \\
5\end{array}$ \\
\hline \multicolumn{2}{|c|}{$\begin{array}{l}\text { X3letakpemerinta } \\
\text { handaerah }\end{array}$} & .405 & .169 & .373 & & \begin{tabular}{r|}
.0 \\
21
\end{tabular} & $9^{.78}$ \\
\hline
\end{tabular}

a. Dependent Variable: Yperilakuoportunistiklegislatif

Sumber: Hasil Penelitian, Data diolah (Januari, 2019).

\section{Pengaruh Pendapatan Sendiri Terhadap Perilaku Oportunistik Legislatif}

Berdasarkan hasil penelitian pendapatan sendiriberpengaruh positif dan signifikan terhadap tingkat penyerapan anggaran di Kabupaten Aceh Utara.Dari hasil penelitian jika dikaitkan dengan kenyataan bahwa pendapatan sendirisangat berpengaruh terhadap tingkat perilaku oportunistik legislatifkarena dengan demikian pendapatan sendiri selama ini 
dianggap penting dalam merencanakan pembangunanpembangunan di Kabupaten Aceh Utara.Secara konseptual, perubahan pendapatan akan berpengaruh terhadap belanja atau pengeluaran, namun tidak selalu seluruh tambahan pendapatan tersebut akan dialokasikan dalam belanja. Secara empiris juga ditemukan adanya flypaper effect yakni adanya perbedaan dalam pola pengeluaran untuk pendapatan dari effort sendiri dengan pendapatan yang diberikan pihak lain (seperti grants atau transfer). Dalam hal pengalokasian berkaitan dengan sumber pembiayaannya dari pendapatan, maka besaran pendapatan akan dimanfaatkan untuk mengatur alokasi belanja.

Hasil penelitian ini sejalan dengan penelitian yang dilakukan oleh Ikhsan Budi Riharjo dan Isnadi, (2009) dan Syukriy Abdullah, (2016)yang menyatakan bahwa pendapatan sendiri berpengaruh positif signifikan terhadap perilaku oportunistik legislatifdi Dewan Perwakilan Rakyat Kabupaten (DPRK) Aceh Utara.

\section{Pengaruh Jenis Pemerintahan Daerah Terhadap Perilaku Oportunistik Legislatif}

Berdasarkan hasil penelitian menyatakan bahwa pengaruh jenis pemerintahan daerah terhadap perilaku oportunistik legislatif memiliki pengaruh yang positif dan signifikan. Hasil penelitian menunjukkan bahwa dengan adanya kejelasan tentang jenis pemerintahan daerah akan memudahkan pemerintah dalam melakukan perilaku anggota dewan yang bersikap oportunistik sehingga penyerapan anggaran sesuai dengan yang diharapkan. Dari hasil penelitian jika dikaitkan dengan kenyataan bahwa pengaruh jenis pemerintah daerah dalam penelitian ini perlu untuk memberikan bukti bahwa intensitas oportunisma legislatif berkaitan dengan status daerah sebagai kota atau kabupaten. Pandangan bahwa perilaku oportunistik legislatif di luar kota atau kabupaten bersumber dari anggapan bahwa social control dari stakeholders di luar pemerintahan terhadap pelaksanaan pelayanan publik dan perilaku anggota legislatif tidak sebaik di dikota. Misalnya, di kota gerakan mahasiswa dan pers sangat efektif dalam mengungkap berbagai penyimpangan anggaran untuk mendorong aparat penegak hukum menindaklanjuti berbagai laporan tentang korupsi dan yang terjadi di lingkungan pemerintahan daerah. Hal yang sama juga terjadi di pemerintahan kabupaten, dimana perbedaan karakteristik masyarakat dan struktur pendapatan berimplikasi pada kontrol sosial yang berbeda pula.

Hasil penelitian ini sejalan dengan penelitian yang dilakukan oleh Ikhsan Budi Riharjo dan Isnadi, (2009) dan Syukriy Abdullah, (2016)yang menyatakan bahwa jenis pemerintahan daerahberpengaruh positif signifikan terhadap perilaku oportunistik legislatifdi Dewan Perwakilan Rakyat Kabupaten (DPRK) Aceh Utara.

\section{Pengaruh Letak Pemerintahan Daerah Terhadap Perilaku Oportunistik Legislatif}

Berdasarkan hasil penelitian menyatakan bahwa pengaruh letak pemerintahan daerah terhadap perilaku oportunistik legislatif memiliki pengaruh yang positif dan signifikan. Hasil penelitian menunjukkan bahwa dengan adanya letak pemerintahan daerah yang jelas akan memudahkan pemerintah dalam melakukan pengawasan terhadap perilaku oportunistik legislatif yang sesuai dengan yang diharapkan.

Dari hasil penelitian jika dikaitkan dengan kenyataan bahwa sama halnya dengan jenis pemerintahan daerah, pengaruh letak pemerintah daerah dalam penelitian ini perlu untuk memberikan bukti bahwa intensitas oportunistik legislatif berkaitan dengan status daerah sebagai kota atau kabupaten. Pandangan bahwa perilaku oportunistik legislatif di luar kota atau kabupaten bersumber dari anggapan bahwa social control dari stakeholders di luar pemerintahan terhadap pelaksanaan pelayanan publik dan perilaku anggota legislatif tidak sebaik di dikota. Perilaku oportunistik yang diperlihatkan legislatif dalam proses penyusunan anggaran tidak berbeda antara legislatif di kota dengan di kabupaten. Artinya, oportunistik melalui anggaran, apakah disebut pencarian rente (rent-seeking) ataupun korupsi, dilakukan oleh legislatif di seluruh Indonesia, baik oleh legislatif di pemerintahan kabupaten maupun di pemerintahan kota.

Hasil penelitian ini sejalan dengan penelitian yang dilakukan oleh Ikhsan Budi Riharjo dan Isnadi, (2009) dan Syukriy Abdullah, (2016)yang menyatakan bahwa letak pemerintahan daerahberpengaruh positif signifikan terhadap perilaku oportunistik legislatifdi Dewan Perwakilan Rakyat Kabupaten Aceh Utara.

\section{Pengaruh Pendapatan Sendiri, Jenis Pemerintahan Daerah dan Letak Pemerintahan Daerah Terhadap Perilaku Oportunistik Legislatif}

Uji-F (uji simultan) dilakukan untuk melihat secara bersama-sama pengaruh positif dan signifikan yang terdiri dari variabel pendapatan sendiri, jenis pemerintahan daerah dan letak pemerintahan daerah terhadap perilaku oportunistik legislatifdi Dewan Perwakilan Rakyat Kabupaten (DPRK) Aceh Utara. Hasil uji-F dapat dilihat pada Tabel 4.13 dibawah ini:

\section{Tabel 8}

Hasil Pengujian Secara Simultan (Uji-F)

\begin{tabular}{|c|c|c|c|c|c|c|}
\hline Model & & $\begin{array}{l}\text { Sum } \\
\text { of } \\
\text { Squa } \\
\text { res }\end{array}$ & df & $\begin{array}{l}\text { Mean } \\
\text { Square }\end{array}$ & $F$ & Sig. \\
\hline 1 & $\begin{array}{l}\text { Regr } \\
\text { essio } \\
n \\
\text { Resi } \\
\text { dual } \\
\text { Total }\end{array}$ & $\begin{array}{r}16.87 \\
6 \\
60.10 \\
2 \\
76.97 \\
8\end{array}$ & $\begin{array}{r}3 \\
41 \\
44\end{array}$ & $\begin{array}{l}5.625 \\
1.466\end{array}$ & $\begin{array}{r}3.83 \\
7\end{array}$ & $\begin{array}{r}.016( \\
\text { a) }\end{array}$ \\
\hline
\end{tabular}

a Predictors: (Constant), pendapatan sendiri, jenis pemerintahan daerah dan letak pemerintahan daerah b Dependent Variable: perilaku oportunistik legislatif Sumber: Hasil Penelitian, Data diolah (Januari, 2019). 
Berdasarkan hasil Tabel 4.13 diatas terlihat nilai $F_{\text {hitung }}$ sebesar 3,837 dengan tingkat signifikansi sebesar 0,000. Sedangkan $F_{\text {tabel }}$ dengan tingkat kepercayaan $95 \%(\alpha=5 \%)$ pada probabilitas 0,05 dan df2=n-k-1 $(45-4=41)$ serta diperoleh nilai $F_{\text {tabel }}$ sebesar 3,998. Maka hasil uji-F menunjukkan bahwa $F_{\text {hitung }}<$ $\mathrm{F}_{\text {tabel }}(3,837<3,998)$. Hasil tersebut membuktikan bahwa tidak menerima $\mathrm{H}_{3}$ dalam artinya pendapatan sendiri, jenis pemerintahan daerah dan letak pemerintahan daerah berpengaruh signifikan terhadap perilaku oportunistik legislatifdi Dewan Perwakilan Rakyat Kabupaten (DPRK) Aceh Utara.

Perilaku oportunistik merupakan perilaku yang berusaha mencapai keinginan dengan segala cara bahkan cara ilegal sekalipun yang dipengaruhi oleh adanya kekuatan (power) dan kemampuan (ability). Dalam proses penganggaran daerah, perilaku oportunistik anggaran (fiscal opportunism) berkaitan dengan perilaku dalam menentukan alokasi belanja dan preferensi yang mengarah pada upaya memberikan keuntungan bagi pihak penyusun anggaran itu sendiri, sehingga kebutuhan masyarakat tidak menjadi prioritas utama.

Perilaku oportunistik pemerintah daerah dalam proses penyusunan anggaran daerah sudah lama menjadi topik kajian akademik. Perilaku oportunistik penganggaran daerah biasanya wujud pada pihak-pihak yang terlibat dalam proses penyusunan anggaran daerah. Perilaku menyimpang tersebut tidak hanya dimulai dari perencanaan, tetapi juga berujung pada proses pelaksanaan anggaran daerah. Munculnya perilaku oportunistik dalam proses penganggaran daerah sebenarnya sudah dibuktikan dalam banyak penelitian empiris.

Hasil penelitian ini sejalan dengan penelitian yang dilakukan oleh Ikhsan Budi Riharjo dan Isnadi, (2009) yang menyatakan bahwa belanja barang dan jasa yang ditetapkan dalam APBD, tidak berpengaruh terhadap slack anggaran dalam penetapan alokasi belanja untuk kemakmuran rakyat.

\section{PENUTUP}

\section{Kesimpulan}

Berdasarkan hasil analisis yang telah dilakukan, maka penulis dapat mengambil beberapa kesimpulan sebagai berikut:

1. Pendapatan sendiriberpengaruh terhadap perilaku oportunistik legislatifdi Kabupaten Aceh Utara. Dari hasil penelitian jika dikaitkan dengan kenyataan bahwa pendapatan sendirisangat berpengaruh terhadap perilaku oportunistik legislatifkarena dengan demikian pendapatan sendiri selama ini dianggap penting dalam merencanakan pembangunanpembangunan di Kabupaten Aceh Utara.

2. Jenis pemerintahan daerah berpengaruh terhadap perilaku oportunistik legislatif di Kabupaten Aceh Utara. Hasil penelitian menunjukkan bahwa dengan adanya kejelasan tentang jenis pemerintahan daerah akan memudahkan pemerintah dalam melakukan perilaku anggota dewan yang bersikap oportunistik sehingga proses pembagian anggaran dalam setiap pembangunan sesuai dengan yang diharapkan.

3. Letak pemerintahan daerah terhadap perilaku oportunistik legislatif memiliki pengaruh yang positif dan signifikan. Hasil penelitian menunjukkan bahwa dengan adanya letak pemerintahan daerah akan memudahkan pemerintah dalam melakukan pengawasan terhadap perilaku oportunistik legislatif yang sesuai dengan yang diharapkan.

\section{Saran}

Berdasarkan hasil penelitian dan kesimpulan, maka terdapat beberapa saran yang penulis sampaikan sehubungan penelitian ini:

1. Disarankan agar data anggaran yang diusulkan eksekutif (APBK) dan yang disahkan (APBK) yang digunakan dalam studi ini dapat dikembangkan dengan menghubungkannya dengan anggaran setelah perubahan (ABT), anggaran realisasi (laporan perhitungan APBK), dan anggaran tahun berikutnya untuk menganalisis bagaimana proses perubahan terjadi dan bagaimana perilaku atau preferensi legislatif terhadap anggaran tersebut.

2. Bagi peneliti selanjutnya, perlu penelitian yang lebih komprehensif untuk membuktikan apakah anggaran belanja yang disahkan akan terealisir seluruhnya sampai ke pelaksana di lapangan. Hal ini untuk membuktikan apakah budget does matter dalam proses pembuatan kebijakan publik. Hal ini akan masuk atau bersinggungan dengan area administrasi publik (public administration) karena sangat berkaitan dengan aspek pemberian pelayanan, transparansi dan akuntabilitas pemerintah daerah.

\section{DAFTAR PUSTAKA}

Arens, A.A, R. J. Elder dan M. S. Beasley. 2008. Auditing and Assurance Services an Integrited Approach. 9th Edition. New Jersey: Person Education, Inc.

Asian Development Bank, 2006. Indonesian Key Indicators. www.adb.org/statistics.

Allard, Richard J. 1995. The measurability of budget related rent-seeking. Public Choice 85: 389-394.

Andvig, Jens Chr., Odd-Helge Fjeldstad, Inge Amundsen, Tone Sissener \& Tina Søreide. 2001. Corruption: A review of contemporary research. Chr. Michelsen Institute Development Studies and Human Rights Report R 2001: 7. Web: http//www.cmi.no/

Albert C. Hyde. 1997. Classics of Public Administration. Fourth edition. Fort Worth: Harcourt Brace College Publisher.

Account of Delegation. Working documents in the Study of European Governance Number: 
5. Center for the Study of European Governance (CSEG).

Colombatto, Enrico. 2001. Discretionary power, rentseeking and corruption. University di Torino \& ICER, working paper.

Davoodi, Hamid R., Erwin R. Tiongson, \& Sawitree S. Asawanuchit. 2003. How Useful Are Benefit Incidence Analyses Of Public Education And Health Spending? IMF Working Paper WP/03/227.

Deller, Steven, Craig Maher, \& Victor Lledo. 2002. Wisconsin Local Government, State Shared Revenues And The Illusive Flypaper Effect. University of WisconsinMadison, working paper.

Devarajan, Shantayanan, Vinaya Swaroop, \& Heng-fu Zou. 1996. The Composition Of Public Expenditure And Economic Growth. Journal of Monetary Economics 37: 313344.

Elgie, Robert \& Erik Jones. 2000. Agents, Principals And The Study of Institutions: Constructing a Principal-Centered

Feyzioglu, Tarhan, Vinaya Swaroop, \& Min Zhu. 1998. A Panel Data Analysis of The Fungibility Of Foreign Aid. World Bank Economic Review 12(1): 29-58.

Fozzard, Adrian. 2001. The Basic Budgeting Problem: Approaches To Resource Allocation In The Public Sector And Their Implications For Pro-Poor Budgeting. Center for Aid and Public Expenditure, Overseas Development Institute (ODI). Working paper 147.

Garamfalvi, L. 1997. Corruption In The Public Expenditures Management Process. Paper presented at 8th International Anti-Corruption Conference, Lima, Peru, 7-11 September.

Ghozali, Imam. (2005). Aplikasi Analisis Multivariate Dengan Program SPSS, Badan Penerbit Universitas Diponegoro, Semarang.

Gilardi, Fabrizio. 2001. Principal-Agent Models Go To Europe: Independent Regulatory Agencies As Ultimate Step Of Delegation. Paper presented at the ECPR General Conference, Canterbury (UK), 6-8 September 2001.

Groehendijk, Nico. 1997. A Principal-Agent Model Of Corruption. Crime, Law \& Social Change 27: 207-229.

Imbeau, Louis M. 2003. Transparency In The Budget Process Of A Bureaucratic Organization: A Principal-Agent Model Of Budgeting. Paper presented at the annual conference of the European Public Choice Society Aarhus, 26-28 April 2003.

Jackson, P. M. 1982. The Political Economy of Bureaucracy. Oxford: Philip Allan.
Jaya, Wihana Kirana. 2005. Dysfunctional Institutions In The Case Of Local Elite Behaviour In Decision-Making About Local Government Budgets In Indonesia. Jurnal Ekonomi dan Bisnis Indonesia 20(2): 120135.

Johnson, Cathy Marie. 1994. The Dynamics of Conflict between Bureaucrats and Legislators. Armonk, New York: M.E. Sharpe., Wolfang \& Manfred E. Streit. 2001. Institutional Economics: Social Order and Public Policy. Cheltham, UK:

Edward Elgar., Philip \& Stuti Khemani. 2003. The Political Economy Of Public Expenditures. Background paper for WDR 2004: Service Work for Poor People. The World Bank.

$\&$ 2004. Democracy, public expenditure and the poor. World bank research observer (forthcoming). Key, V.O. 1940. The lack of budgetary theory. American Political Science Review 34 (December).

Krueger, A. 1974. The Political Economy of the RentSeeking Society. American Economic Review 64 (3), 291-303.

Lane, Jan-Erik. 2003. Management And Public Organization: The Principal-Agent Framework. University of Geneva and National University of Singapore. Working Paper.

Lee, Robert D. Jr. \& Ronald W. Johnson. 1998. Public Budgeting Systems. Sixth edition. Gaithersburg, Maryland: Aspen Publishers, Inc.

Lupia, Arthur \& Mathew McCubbins. 2000. Representation Or Abdication? How Citizens Use Institutions To Help Delegation Succeed. European Journal of Political Research 37: 291-307.

Mushtaq H. \& Jomo Kwame Sundaram (Eds.). 2000. Rents, Rent-Seeking and Economic Development -Theory and Evidence in Asia. Singapore: Cambridge University Press.

Magner, Nace \& Gary G. Johnson. 1995. Municipal Officials' Reactions To Justice In Budgetary Resource Allocation. Public Administration Quarterly (Winter): 439456.

Mardiasmo. 2002. Otonomi dan Manajemen Keuangan 
Mauro, Paolo. 1998a. Corruption and the composition of government expenditure. Journal of Public Economics 69: 263-279.

Moisio, Antti. 2002. Essays on Finish Municipal Finance and Intergovernmental Grants. Helsinki: Government Institute for Economic Research. http://vatt.fi.

Mueller, Bernardo \& Carlos Pereira. 2003. Democratic governance and budget allocation in Latin America: Electoral rules and legislative organization - Two complementary dimensions of the cost of governing. Universidade de Brasilia \& University of Oxford, working paper.

Petrie, Murray. 2002. A framework for public sector performance contracting. OECD Journal on Budgeting: 117-153.

Rubin, Irene S. 1993. The Politics of Public Budgeting: Getting and Spending, Borrowing and Balancing. Second edition. Chatam, NJ: Chatham House Publishers, Inc.

Samuels, David. 2000. Fiscal horizontal accountability? Toward theory of budgetary "checks and balances" in presidential systems. University of Minnesota, working paper presented at the Conference on Horizontal Accountability in New Democracies, University of Notre Dame, May.s

Shleifer, A. \& R. Vishny. 1993. Corruption. Quarterly Journal of Economics 108: 599-617. Smith, Robert W. \& Mark Bertozzi. 1998. Principals and agents: An explanatory model of public budgeting. Journal of Public Budgeting, Accounting and Financial Management (Fall): 325-353.

Stiglitz, Joseph E. 1999. Economics of the Public Sector. Third edition. New York: W.W. Norton \& Company.

Strom, K. 2000. Delegation and accountability in parliamentary democracies. European Journal of Political Research 37: 261-289.

Tanzi, Vito \& Hamid Davoodi. 2002. Corruption, public investment, and growth, dalam Abed, George T. \& Sanjeev Gupta (eds.). 2002. Governance, Corruption, \& Economic Performance. Washington, D.C.: International Monetary Fund.

Von Hagen, Jurgen. 2002. Fiscal rules, fiscal institutions, and fiscal performance. The Economic and Social review 33 (3): 263284. 